\title{
Cannabis joint triggered recurrent anterior myocardial infarction in an adolescent taking dual anti-platelet therapy
}

Nawrót zawału ściany przedniej serca wywołany paleniem konopi indyjskich u młodego pacjenta stosującego podwójną terapię przeciwpłytkową

\author{
Ismail Biyik', Ibrahim Faruk Akturk², Ahmet Arif Yalcin', Ibrahim Cansaran Tanidir², Mehmet Erturk ${ }^{1}$ \\ 1Department of Cardiology, Istanbul Mehmet Akif Ersoy, Thoracic and Cardiovascular Surgery Center and Research Hospital, Istanbul, Turkey \\ 2Department of Pediatric Cardiology, Istanbul Mehmet Akif Ersoy, Thoracic and Cardiovascular Surgery Center and Research Hospital, Istanbul, \\ Turkey
}

Postep Kardiol Inter 2012; 8, 2 (28): 156-159 DOI: 10.5114 /pwki.2012.29658

\begin{abstract}
Cannabis smoking has been rising world-wide especially in industrialized western countries. It has been known that cannabis use has adverse effects on the heart and vascular system and an increased risk of acute myocardial infarction (AMI) has been reported. The actual mechanism of cannabis-related AMI is not well known. In this report, we describe an adolescent with cannabis-induced recurrent left anterior descending coronary artery thrombosis and anterior myocardial infarction even on dual anti-platelet therapy.
\end{abstract}

Key words: cannabis, marijuana, recurrent myocardial infarction, dual anti-platelet therapy

\section{Streszczenie}

Palenie konopi indyjskich rozpowszechnia się zwłaszcza w uprzemysłowionych krajach zachodnich. Udowodniono, że negatywnie wpływa ono na serce i układ naczyniowy oraz zwiększa ryzyko wystąpienia ostrego zawału serca. Dokładny mechanizm zawału serca wywołanego przez konopie indyjskie nie jest znany. Przedstawiamy przypadek młodego pacjenta z nawrotem zakrzepicy w gałęzi przedniej zstępującej i ostrym zawałem serca, mimo stosowania podwójnej terapii przeciwpłytkowej.

Słowa kluczowe: konopie indyjskie, marihuana, nawrót zawału serca, podwójna terapia przeciwpłytkowa

\section{Introduction}

Various preparations of the plant Cannabis sativa are used especially for their euphoric effects. It is a common substance of abuse world-wide. According to the report of the European Monitoring Centre for Drugs and Drug Addiction, $31.1 \%$ of adults in the European Union (aged 15-24 years) have tried cannabis at least once in their life [1]. Adverse effects of cannabis on the cardiovascular system have been recognized for the last four decades [2]. In the present report, we describe an adolescent with cannabisinduced recurrent left anterior descending (LAD) coronary artery thrombosis and anterior ST elevation acute myocardial infarction (AMI) even on dual anti-platelet therapy.

\section{Case report}

A 19-year-old adolescent presented to the emergency department with chest pain lasting about $1 \mathrm{~h}$. He had no history of previous cardiac disease. He had no other coronary risk factors except cigarette smoking with ten cigarettes per day for 3 years. He had been smoking cannabis cigars with one joint per 1 or 2 months for 1 year. He had smoked one joint of cannabis about one hour before chest pain. His physical examination was unremarkable. A 12lead electrocardiogram showed 3 to $6 \mathrm{~mm}$ ST elevation in leads DI, aVL and V1-V6, respectively. His initial biochemical profile including cardiac troponins and creatinine kinase MB enzymes was normal. Because the ECG changes and 
clinical course were nearly specific for acute anterior ST elevation myocardial infarction, the patient was transferred to the catheterization laboratory for urgent coronary angiography and primary angioplasty after 300 mg acetylsalicylic acid, $600 \mathrm{mg}$ clopidogrel and 5000 units of unfractionated heparin were given.

Coronary angiography revealed total occlusion of the proximal left anterior descending coronary artery. Other coronary arteries were noted as normal. Thrombolysis in Myocardial Infarction (TIMI) grade 0 flow was seen beyond the occlusion site of the LAD artery (Figure 1 A). The occlusion site was crossed with a floppy wire (Guidant Corporation, USA) and predilatation was made with a compliant balloon catheter (Medtronic, USA). TIMI grade 1 flow and huge thrombus burden were seen at mid and distal segments of the LAD artery. Thrombus burden was successfully aspirated with an export catheter (Medtronic USA) and TIMI grade III flow was reestablished (Figure $1 \mathrm{~B}$ ). Since there was neither coronary dissection nor atherosclerotic plague rupture at the occlusion site of the LAD artery, stenting was not performed. The patient was admitted to the coronary care unit and tirofiban infusion with appropriate doses was started. After the intervention, cardiac markers including troponins and creatinine kinase MB increased to levels consistent with AMI. Echocardiography showed mild hypokinesis at the anterior and anteroseptal walls. Left ventricular ejection fraction was counted as $50 \%$. His further blood tests revealed normal values of glucose, cholesterol and other lipids, and thrombotic and connective tissue disorder screening tests consisting of protein $\mathrm{S}$ and C, antithrombin-III activity, lupus anticoagulant, cardiolipin antibodies, factor $V$ Leiden mutation, prothrombin gene mutation, and homocysteine levels were all found to be in normal ranges or negative. After 5 days of hospitalization, the patient was discharged with dual anti-platelet therapy (clopidogrel $75 \mathrm{mg}$ and acetylsalicylic acid $300 \mathrm{mg}$ once a day) and referred to an addiction treatment center for psychiatric examination and therapy. Forty-five days after discharge, he presented again to the emergency department with similar chest pain lasting about $2 \mathrm{~h}$. He had smoked one joint of cannabis $3 \mathrm{~h}$ before chest pain. He had been taking dual anti-platelet therapy as previously prescribed. His physical examination was normal except mild hypotension $(90 / 60 \mathrm{~mm} \mathrm{Hg})$. His electrocardiogram revealed 5 to $6 \mathrm{~mm}$ ST elevation in leads V1-V6. Because the patient's clinical presentation and ECG changes were consistent with recurrent anterior ST elevation AMI, the patient was transferred to the catheterization laboratory for urgent angiography and primary angioplasty again. Repeated coronary angiography revealed total occlusion of the proximal left anterior descending artery with TIMI flow grade 0 (Figure $2 \mathrm{~A}$ ). Other coronary arteries were still normal. The occlusion site was crossed with a floppy wire (Guidant Corporation, USA) and dilated with a compliant balloon catheter (Medtronic, USA). TIMI grade III flow was reestablished (Figure $2 \mathrm{~A}$ ). Because neither coronary dissection nor atherosclerotic plague rupture at the occlusion site of the LAD artery was seen, stenting was still not performed. Tirofiban infusion was administered. After the procedure, cardiac enzymes increased to levels consistent with AMI. Control coronary angiography prior to discharge was performed and revealed TIMI grade III flow at the LAD artery. Neither ruptured plaque nor coronary dissection was seen at the LAD artery. Pre-discharge echocardiogra-
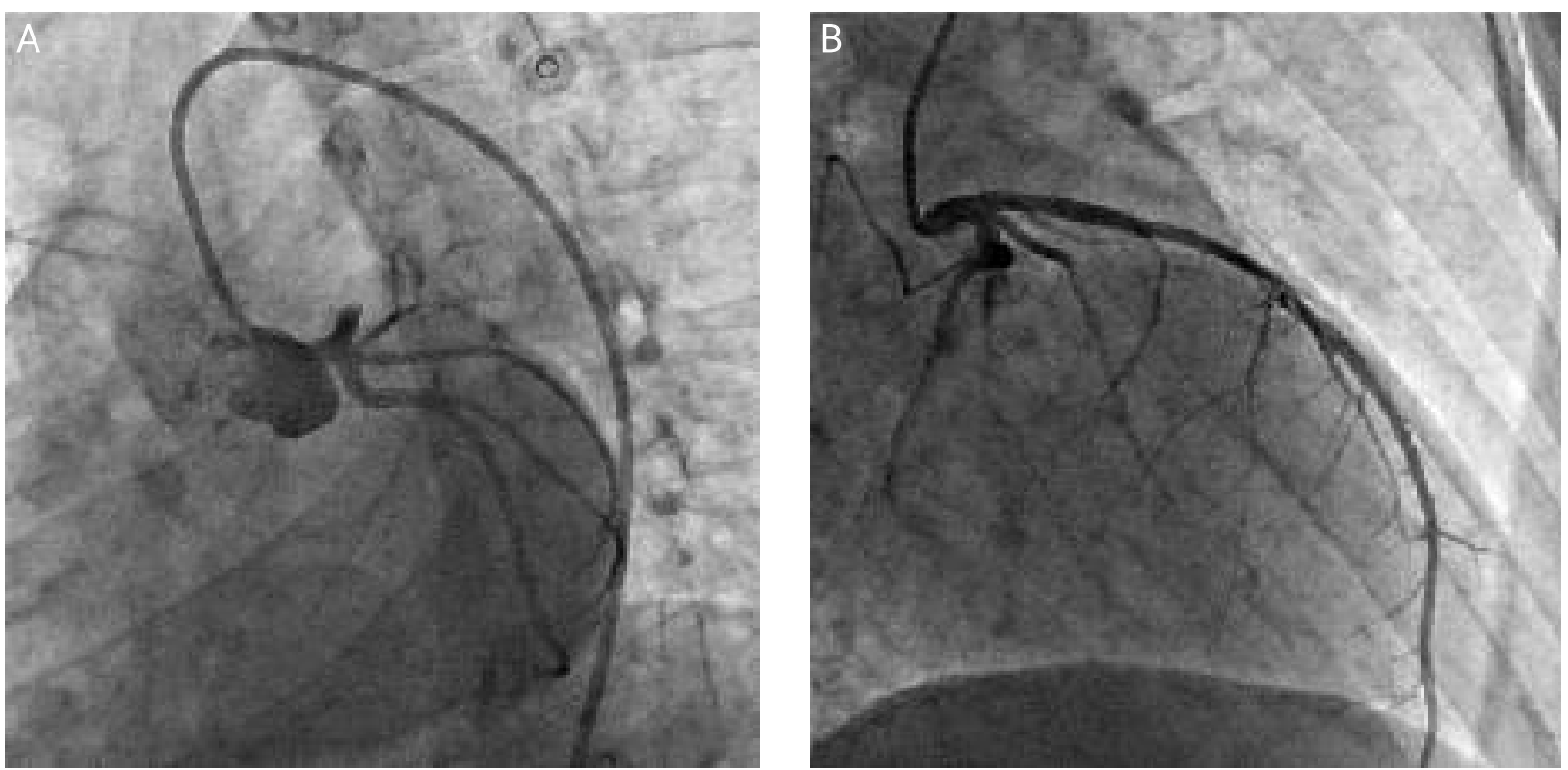

Fig. 1. Total occlusion of $L A D$ artery at first admission (A). View of LAD artery after thrombus aspiration (B) Ryc. 1. Całkowita niedrożność $L A D$ podczas pierwszej hospitalizacji $(\boldsymbol{A})$. Obraz $L A D$ po aspiracji skrzepliny $(\boldsymbol{B})$ 

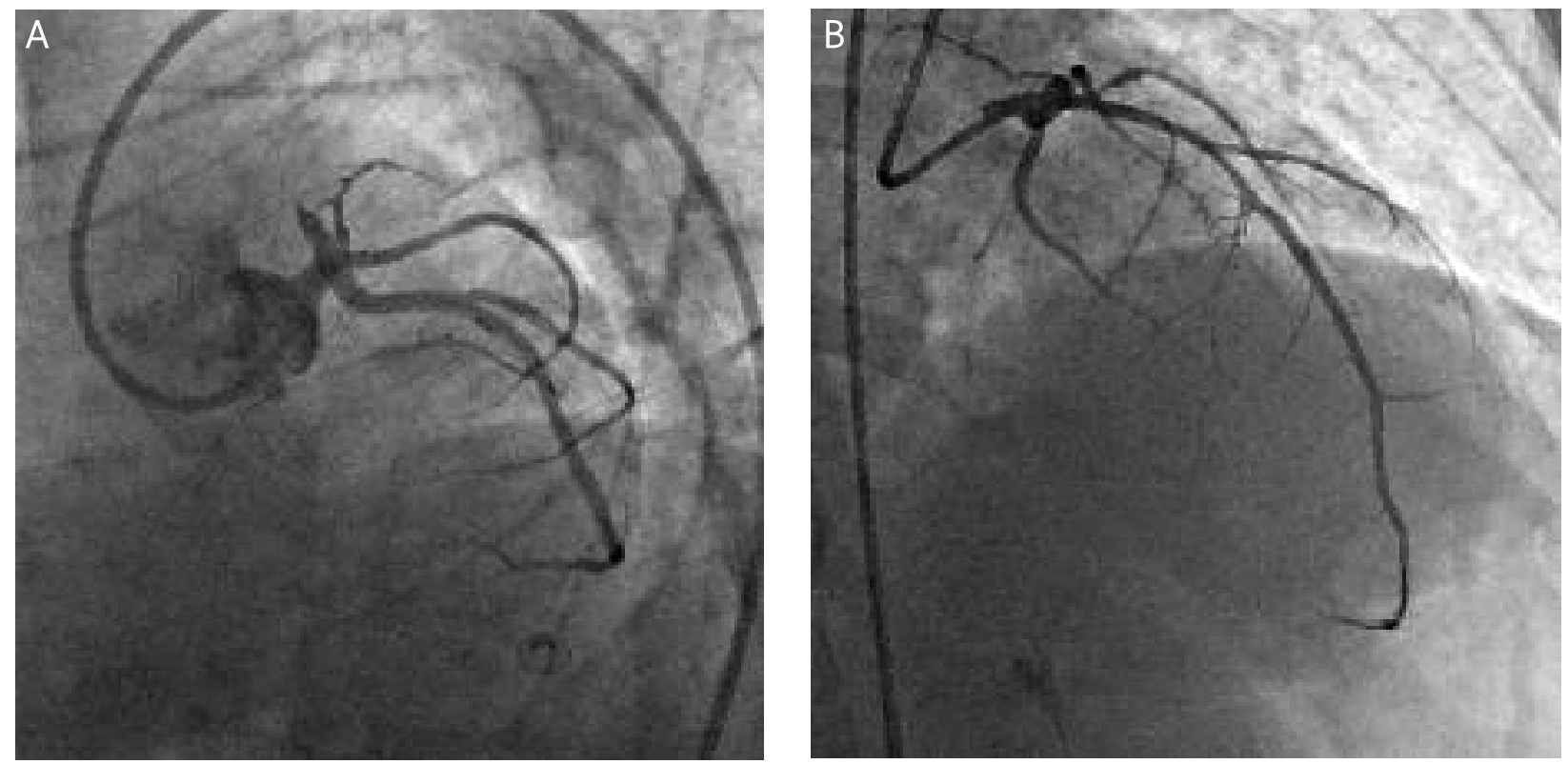

Fig. 2. Total occlusion of LAD artery at $2^{\text {nd }}$ admission (A). View of $L A D$ artery after $2^{\text {nd }}$ balloon angioplasty (B) Ryc. 2. Catkowita niedrożność $L A D$ w czasie drugiej hospitalizacji $(A)$. Obraz LAD po drugiej angioplastyce balonowej (B)

phy revealed $35 \%$ left ventricular ejection fraction and severe hypokinesis at anterior, apical and anteroseptal segments of the left ventricle. Seven days after admission, the patient was discharged with medical therapy consisting of clopidogrel 75 mg/day, acetylsalicylic acid 300 mg/day, ramipril $10 \mathrm{mg} /$ day, furosemide $40 \mathrm{mg} /$ day and metoprolol $50 \mathrm{mg} /$ day. The patient has remained under follow-up about for one year and there has been no other cannabis usage or coronary event in this period.

\section{Discussion}

Cannabis is derived from the plant Cannabis sativa. It is a common substance of abuse in the world [2]. To date, numerous cases of AMI associated with cannabis usage have been reported in the medical literature. We wanted to emphasize that the risk of AMI after cannabis smoking should be considered and cannabis joints might cause recurrent coronary thrombosis even if the patient is on dual anti-platelet therapy and even if he is a very young adolescent.

Although marijuana is known to contain over sixty chemical entities, the major pharmacologically active compound is delta 9 tetrahydrocannabinol (THC) [3]. The THC content in marijuana is variable, depending on strain and growth conditions. The biological effects of cannabinoids are mediated through endogenous cannabinoid receptors which are found in a variety of tissues including the brain, heart and blood vessels [3]. Cannabis is rapidly absorbed through the lungs during cannabis smoking. The concentration of THC in the bloodstream reaches peak levels even before the end of the smoking period and then it is rapidly distributed to the tissues. There are comprehensive reviews and case reports that reveal that cannabis is a trigger of adverse cardiovascular events including AMI [3-5]. The potential mechanisms of coronary thrombosis associated with cannabis use are vasospasm, sluggish coronary flow, endothelial dysfunction by reduced availability of nitric oxide, necrotizing angiitis leading to thromboembolism, activation of platelets by enhancing expression of glycoprotein IIb-IIla and P-selectin on platelet surface in a concentration-dependent manner, activation of factor VII, and nonreversible platelet aggregation with higher concentrations of cannabis metabolites [3-6]. It is reported that risk of developing an AMI is 4.8 times higher within the first hour following cannabis use [7]. Direct activation of platelets by enhancing expression of glycoprotein IIb-IIIa and P-selectin on platelet surface by THC might be the mechanism responsible for the recurrent $A M I$ in this case on dual antiplatelet therapy [6]. Thus, dual antiplatelet therapy with acetylsalicylic acid and clopidogrel might not prevent future cardiovascular events associated with cannabis smoking.

The optimal treatment strategy for cannabis-induced myocardial infarction is also not well known. Stenting is the preferred approach in patients with atherosclerotic plaque rupture or dissection [8, 9]. However, in very young patients without plaque rupture or dissection, as in our case, balloon angioplasty and thrombus aspiration might be a good alternative approach to stenting to avoid the risk of stent thrombosis and restenosis at a young age. Thrombolytic therapy might be another alternative approach [10]. 


\section{Conclusions}

Cannabis use should be kept in mind and questioned in young patients with acute coronary syndrome. Cannabis smokers should be warned about its rare potential hazardous effects. Moreover, effects of cannabis on platelet functions under dual antiplatelet therapy with clopidogrel and acetylsalicylic acid are not known. Cannabis might trigger vascular thrombosis with different mechanisms independent of the effects of both clopidogrel and acetylsalicylic acid, or might cause resistance to these drugs.

\section{References}

1. European Monitoring Centre for Drugs and Drug Addiction, 2009 Annual report on the state of the drugs problem in Europe, Luxembourg. Cannabis 2009; 3: 38-47.

2. Aryana A, Williams MA. Marijuana as a trigger of cardiovascular events: speculation or scientific certainty? Int J Cardiol 2007; 118: 141-144.

3. Caldicott DG, Holmes J, Roberts-Thomson KC, Mahar L. Keep off the grass: marijuana use and acute cardiovascular events. Eur J Emerg Med 2005; 12: 236-244.

4. Lindsaya AC, Foalea RA, Warrenb O, et al. Cannabis as a precipitant of cardiovascular emergencies. Int J Cardiol 2005; 104: 230-232.

5. Heiden D, Rodvien R, Jones R, et al. Effects of oral delta-9tetrahydrocannabinol on coagulation. Thromb Res 1980; 17: 885-889.

6. Deusch E, Kress HG, Kraft B, et al. The procoagulatory effects of delta-9-tetrahydrocannabinol in human platelets. Anesth Analg 2004; 99: 1127-1130.

7. Mittleman MA, Lewis RA, Maclure M, et al. Triggering myocardial infarction by marijuana. Circulation 2001; 103: 2805-2809.

8. Canga Y, Osmonov D, Karatas MB, et al. Cannabis: a rare trigger of premature myocardial infarction. Anadolu Kardiyol Derg 2011; 11: 271-275.

9. Kocabay G, Yildiz M, Duran NE, Ozkan M. Acute inferior myocardial infarction due to cannabis smoking in a young man. J Cardiovasc Med (Hagerstown) 2009; 10: 669-670.

10. Tatli E, Yilmaztepe M, Altun G, Altun A. Cannabis-induced coronary artery thrombosis and acute anterior myocardial infarction in a young man. Int I Cardiol 2007; 120: 420-422. 